LIQUIDITY MODELS IN OPEN ECONOMIES:

THEORY AND EMPIRICAL EVIDENCE

Nouriel Roubini

Vittorio Grilli

Working Paper 5313 


\title{
LIQUIDITY MODELS IN OPEN ECONOMIES: THEORY AND EMPIRICAL EVIDENCE
}

\author{
Nouriel Roubini \\ Vittorio Grilli
}

Working Paper 5313

\author{
NATIONAL BUREAU OF ECONOMIC RESEARCH \\ 1050 Massachusetts Avenue \\ Cambridge, MA 02138 \\ October 1995
}

This paper is part of NBER's research program in International Finance and Macroeconomics. Any opinions expressed are those of the authors and not those of the National Bureau of Economic Research.

(c) 1995 by Nouriel Roubini and Vittorio Grilli. All rights reserved. Short sections of text, not to exceed two paragraphs, may be quoted without explicit permission provided that full credit, including $\odot$ notice, is given to the source. 


\title{
LIQUIDITY MODELS IN OPEN ECONOMIES: \\ THEORY AND EMPIRICAL EVIDENCE
}

\begin{abstract}
This paper presents an overview of recent theoretical and empirical research on "liquidity models" in open economies; this is a class of optimizing models where money has effects on real asset prices and economic activity without relying on the "ad-hoc" assumption of price/wage stickiness. The non-neutrality of money derives from a temporary segmentation between goods and asset markets. After surveying the theoretical literature on liquidity models, we present empirical evidence based on VAR econometric techniques for the seven major industrial countries. Such evidence is shown to be consistent with the main implications of the liquidity models.

Nouriel Roubini

Department of Economics, MEC 7-83

Stern School of Business

New York University

New York, NY 10012-1126

and NBER

Vittorio Grilli

Ministero del Tesoro

Direzione Generale del Tesoro

Capo del Servizio I

via XX Settembre 97

Roma 00187

ITALY

and NBER
\end{abstract}


This paper presents an overview of our theoretical and empirical research on "liquidity models" in open economies. The term "liquidity models" refers to a class of models where money has effects on real asset prices and economic activity without relying on the "ad-hoc" assumption of price/wage stickiness. These are optimizing models based on micro-foundations where agents maximize utility, firms maximize profits and agents hold rational expectations; moreover, all prices and wages are instantaneously flexible. The nonneutrality of money derives from a temporary segmentation between goods and asset markets: portfolio choices cannot be adjusted instantaneously following innovations in policy or shocks. In a sense, sticky price models assume that adjustment in asset markets is instantaneous while the one in goods market is slow; while liquidity models assume that adjustment in asset markets is slow while the one in goods market is instantaneous.

The first paper in the literature is the one by Lucas (1990). He considers a simple standard cash-in-advance model in a tree economy. Assume that money is needed to buy both goods and financial assets; so there are two cash-in-advance constraints, one for goods markets and one for asset markets. Then, the household has to decide in advance (of the stochastic monetary shock) how much money to bring to the goods market to buy goods and how much to save to buy assets (here government bonds). Once this portfolio decision has been made at the beginning of the period no further portfolio adjustment is allowed in the period. Since agents need money to buy assets, once the monetary disturbance is revealed (a stochastic open market operation changing the supply of government bonds), this monetary disturbance will affect the price of bonds and the nominal and real interest rates. If the bonds supply increases, bonds prices will fall and interest rates will go up to clear the bond market, given the amount of money available to buy bonds. Real asset 
prices are affected because the disturbance does not affect the growth rate of money and the expected inflation rate. Therefore, asset prices show an "excess volatility" since they vary more than explained by their traditional fundamentals.

In Grilli and Roubini (1992), we present a two-country open economy version of Lucas' model. The mechanism is the same and the basic result is that purely nominal monetary shocks will affect not only interest rates but also nominal and real exchange rates. The "excess volatility" result applies to the nominal and real exchange rate too. In Roubini and Grilli (1993) we present a deterministic version of this two-country model and show the effects of capital controls and public debt management on the level of the exchange rate.

The limit of the Lucas (1990) and the Grilli and Roubini $(1992,1993)$ models is that the economy is assumed to be characterized by a tree economy: i.e. production is stochastic but exogenous. Fuerst (1992) presents a Lucas type of closed economy model where production occurs via use of labor and capital inputs so that these monetary shocks have real effects on output. The cash in advance constraints are slightly different: households decide in advance how much money to bring to the goods market to buy goods and how much to put in deposit accounts in banks. Banks in turn lend these funds to firms. The second cash-in-advance constraint affects firms: they have to borrow money in advance from banks in order to pay for working capital (wages and intermediate inputs). Again, the portfolio decisions are sticky. Now, positive stochastic monetary injections by the central bank to the commercial banks will affect the liquidity of the system. Given the demand of loans by firms, the nominal interest rate will fall in order to clear the credit market. Then, with lower interest rates, firms will borrow more and therefore will increase their demand 
of labor and working capital. Therefore, a monetary disturbance will temporarily increase output and the level of economic activity. The transmission effect of monetary policy is via the aggregate supply channel rather than the aggregate demand channel of sticky

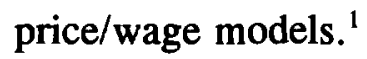

In Roubini and Grilli (1991) we present a two-country deterministic version of the Fuerst model with perfect capital mobility (free trade in capital goods and financial assets). Here monetary shocks in one country will affect nominal and real interest rates and exchange rates as well as output in the domestic economy and the foreign one. The spillovers of monetary policy across countries are positive rather than negative as in the Mundell-Flemming model. ${ }^{2}$

Empirical studies of the implications of liquidity effects models include Christiano and Eichenbaum (1992a, 1992b) for closed economies; for open economies, Eichenbaum and Evans (1995) for the U.S. and Grilli and Roubini (1995) and Kim and Roubini (1995) for the other G-7 countries. The latter two studies consider empirically a number of puzzles that have plagued the empirical literature on the effects of monetary policy in closed and open economies. Such puzzles can be summarized as follows:

1. The liquidity puzzle. When monetary policy shocks are identified as innovations in monetary aggregates (such as M0, M1, M2, etc.), such innovations appear to be associated with increases rather than decreases in nominal interest rates.

2. The price puzzle. When monetary policy shocks are identified with innovations in interest rates, the output and money supply responses are correct as a contractionary increase in interest rates is associated with a fall in the money supply and the level of 
economic activity. However, the response of the price level is wrong as the monetary tightening is associated with a persistent increase in the price level rather than a decrease.

3. The exchange rate puzzle. While a positive innovation in interest rates in the United States is associated with an impact appreciation of the U.S. dollar relative to the other G-7 currencies, such monetary contractions in the other G-7 countries are often associated with an impact depreciation of their currency value relative to the U.S. dollar.

4. The forward discount bias puzzle. If uncovered interest parity holds, a positive innovation in domestic interest rates relative to foreign ones should be associated with a persistent depreciation of the domestic currency after the impact appreciation, as the positive interest rate differential leads to an expected depreciation of the currency. However, the data show that a positive interest differential is associated with a persistent appreciation of the domestic currency for periods up to two years after the initial monetary policy shock.

In Grilli and Roubini (1995) we address the exchange rate and liquidity puzzles. We use an unrestricted VAR approach and consider the monetary policy in the G-7 countries in the flexible exchange rate period (monthly data for the 1974-1991 period). To consider the liquidity puzzle we identify monetary policy with innovations in short term interest rates. We model two-country VAR systems (the non-U.S. G-7 countries relative to the U.S.). In Figure 1 we present the impulse response functions to positive short-term interest rate innovations in each of the G-7 countries other than the U.S. (Japan, Germany, France, United Kingdom, Italy and Canada) using a 7-variable VAR system. The variables ordering in each of these six VAR systems is: domestic industrial production, domestic CPI inflation, U.S. industrial production, U.S. CPI inflation, U.S. short term interest rate, 
domestic short term interest rate and the nominal exchange rate of the country considered relative to the U.S. dollar (defined as units of domestic currency per one unit of U.S. dollars).

The results show strong evidence of an exchange rate puzzle: following a monetary contraction (an increase in short term interest rates) the Deutsche Mark, French Franc, Italian Lira and Canadian Dollar depreciate on impact relative to the U.S. dollar (rather than appreciate as suggested by most exchange rate models). We present in the figure intervals of confidence for the point estimates of these impulse responses. These are the dashed lines in the figures and represent a one standard deviation band around the coefficient estimates. The confidence bands imply that the impact depreciations are statistically significant for the cases of Germany and Italy but not in the French case. In the case of the Japan, U.K. and Canada the impact effect of a domestic interest rate shock is an appreciation of the exchange rate but the result is not statistically significant. These puzzling results contrast with those obtained for U.S. monetary shocks where the Dollar always appreciates significantly on impact following a monetary tightening in the U.S. (see Grilli and Roubini (1995)).

Apart from the above puzzling impact effects, there is also evidence of a "forward discount bias puzzle": in five of the countries the impulse responses show a persistent appreciation over time of the currencies after the impact response; the maximal appreciation does not occur on impact but rather around one year later. This persistent appreciation of the currencies implies a failure of the uncovered interest parity condition (UIPC): the currencies should fall after the impact appreciation since the positive 
differential between domestic rates and U.S. rates should lead to an expected dollar depreciation under the UIPC.

In Grilli and Roubini (1995) we offer two explanations of the "exchange rate puzzle"; one is based on the idea that the U.S. is the "leader" country in the setting of monetary policy for the G-7 area, while the other countries are "followers". The other one suggests that interest rate innovations in the non-U.S. G-7 countries occur as an endogenous policy reaction to inflationary shocks that cause of exchange rate depreciation.

Specifically, past and current inflation rates in the VAR may not be capturing correctly changes in expected inflation through current and past values of the inflation rate if inflationary shocks built in the price of imported intermediate inputs (or fiscal deficits expected to be monetized) have not passed through to domestic prices yet. In this regard, the evidence about a "price puzzle" found by Sims (1992) and others, i.e. that contractionary interest rate innovations are often associated with price level increases rather than decreases, adds some credit to such an argument. In fact, figure 1 shows that interest rate innovations are always associated with a positive impulse response for the inflation rate, suggesting that interest rate increases are partly due to Fisherian reasons and/or to the policy response to increases in expected inflation.

Since we need to find better proxies for expected inflation, it is likely that movements in long term interest rates might be capturing quite well agents' expectations about long term inflationary trends. Then, a good proxy of the degree of tightness of monetary policy might be the differential between short term and long term interest rates. This variable might be a good measure of real interest rate movements since it captures movements of short term rates not due to expected inflation. Therefore, in the first two 
rows of figure 2 , we present the results of a seven variable VAR system similar to that in figure 1 , where we substituted the short term interest rate with the differential between short and long term interest rates. The exchange rate puzzle is now solved for France, Germany, Japan, Canada and the U.K. (but not Italy), as the response to a domestic interest rate innovation is now a significant impact currency appreciation. Moreover, in four of these countries (the U.K being an exception), the significant appreciation of the currency persists over time, as the maximal appreciation occurs several months after the shock. These results suggest that controlling for expected inflation with the long rate is important in identifying monetary contractions with increases in short-term rates and obtain the predicted impact appreciation of the exchange rate.

Next, in the last two rows of figure 2 we present the effects of these interest rate shocks on economic activity (industrial production) and real exchange rates. These results come from an estimated VAR similar to the one in the top part of figure 2, where we substituted the nominal exchange rate with the real exchange rate of the country relative to the U.S.. We consider again the impulse responses to a shock in the short-long rate differential. The last two rows of Figure 2 show that the responses of real exchange rates and output are consistent with the predictions of models suggesting non-neutralities of monetary policy. Note that in the short run the behavior of the real exchange follows closely that of the nominal exchange rate: we get a statistically significant impact and persistent appreciation of the real exchange rate in France, Germany, Japan and Canada. In Italy, the initial insignificant real depreciation is followed by a persistent appreciation, while in the U.K. the initial nominal and real appreciation is followed by a depreciation. ${ }^{3}$ While being persistent, the real appreciation of the exchange rate in France, Germany, 
Japan and Canada is temporary: the real exchange rate returns to its pre-shock value in about three years. This is consistent with temporary real effects of monetary shocks. In spite of a puzzling dynamic path, a similar mean reversion is observed in Italy and the U.K. .

Moreover, the output responses are quite consistent with the effects of a monetary contraction: the increase in interest rates leads, over time, to a statistically significant fall in output in France, Italy, U.,K. Japan and Canada. In Germany, the fall in output occurs only after a six month lag but is not statistically significant. The fall in output tends to be persistent but transitory in most countries, as the output turns back towards its steady state value after about three years.

While the empirical methodology used by Grilli and Roubini (1995) addresses a number of the above puzzles, there are some limitations to this analysis. First, the recursive structure of the identification restrictions is quite unrealistic. The world is likely to be much less recursive than what is assumed in this identification scheme. Second, in order to obtain an impact effect of interest rate innovations on the exchange rate one has to put the exchange rate after the domestic interest rate in the VAR ordering. This implies that monetary policy does not contemporaneously respond to shocks to the exchange rate. Third, the identification proposed by Grilli and Roubini (1995) still leads to a forward discount bias puzzle even when the impact response of the exchange rate becomes correct. Fourth, the above approach gives only a partial solution of the price puzzle.

Since work by Sims and Zha (1995) for a closed economy suggests that an identified (structural) VAR approach has the promise of addressing better the above problems, Kim and Roubini (1995) develop an identified VAR approach for open economy models and 
apply this approach to the same G-7 countries and sample period as in Grilli and Roubini (1995). The structural identification, described in detail in Kim and Roubini (1995), implies that the model is composed of several blocks. The first two equations describe the money market equilibrium - money supply and money demand equations. The next two describe the domestic goods market equilibrium (output and price determination equations); the fifth and sixth equations represent the exogenous shocks coming from the world economy, the U.S. interest rate (FFR) and the oil price (OPW) shocks. The last is the arbitrage equation describing the exchange rate market.

In Figure 3, we display the estimated impulse responses in each non-U.S. G-6 countries to a contractionary monetary policy shock. Initially the interest rate (CR) significantly increases and the money supply (M) significantly falls in all six countries. In all countries the price level (CPI) declines smoothly and significantly at least over some horizon. Moreover, in all countries the output (IP) falls over some horizon following the monetary contraction and the effect is significant in all cases but Italy. A mean reversion of output to its initial level is also clear in most countries. The impact effect of the monetary contraction on the exchange rate $(E(/ \$))$ is an appreciation; with the exception of France, such impact appreciation is statistically significant. The model fares also well with regards to the dynamic response of the exchange rate over time: the initial impact appreciation of the currency is not followed by the long and persistent appreciation found in Eichenbaum and Evans (1995) and Grilli and Roubini (1995). In almost all cases, after the initial impact appreciation, the exchange rate starts to depreciate quite quickly. While this depreciation does not occur right after the impact appreciation, we do not observe either the persistent appreciation for over two years found in previous work. Therefore, 
the forward discount bias is much less evident in this structural VAR identification scheme.

Results qualitatively similar to those in figure 3 are obtained for the effects of U.S. monetary policy shocks in an appropriately identified VAR model for the United States (see Kim and Roubini (1995). In summary, the structural VAR approach appears to be quite successful in explaining all the puzzles that plagued the recent literature on the effects of monetary policy in closed and open economies.

The evidence about the real effects of monetary shocks presented in Grilli and Roubini (1995) and Kim and Roubini (1995) is consistent with the implications of "liquidity models" and clearly inconsistent with flexible price models with monetary neutrality. However, it is not easy to draw inferences about the relative performance of "liquidity models" (Roubini and Grilli (1991, 1992, 1993) with flexible price and slow portfolio adjustment relative to models with sticky prices and instantaneous portfolio adjustment (Dormbusch (1976)). Empirically, both types of models imply that monetary shocks have real effects and have similar empirical implications: following a monetary expansion, interest rates will fall, nominal and real exchange rate will depreciate and output will increase until agents have fully adjusted their price and/or portfolio decisions. The only difference is that, in liquidity models output increases via a aggregate supply channel while in sticky price models the output effects are due to an increase in aggregate demand. This equivalence implies that the empirical tests in these papers cannot be used to discriminate between the two types of models. 


\section{Endnotes}

1. The simple liquidity model cannot account for the persistency of the monetary shocks on interest rates and output. Adjustment costs are infinite in the assets market in the first period and zero in the following period; so the output and interest rate effects are very short term. In order to get the realistic persistency of these real effects, one has to introduce convex cost of adjustment in the portfolio decision (as in Christiano and Eichenbaum (1992b)).

2. Stochastic versions of Roubini and Grilli (1991) are presented by Schlagenhauf and Wrase (1995).

3. The results on the real exchange rate are consistent with those in Clarida and Gali (1994) who use a structural VAR approach.

\section{References}

Christiano, L. and M. Eichenbaum (1992a) "Liquidity Effects, Monetary Policy and the Business Cycle", NBER Working Paper No.4129; forthcoming Journal of Money, Credit and Banking.

Christiano, L. and M.Eichenbaum (1992b) "Liquidity Effects and the Monetary Transmission Mechanism," American Economic Review Papers and Proceedings, May.

Clarida, R. and J. Gali (1994) "Sources of Real Exchange Rate Fluctuations: How Important are Nominal Shocks?," Carnegie Rochester Conference Series on Public Policy.

Dombusch, R. (1976) "Expectations and Exchange Rates Dynamics", Journal of Political Economy, Vol.84.

Eichenbaum, M. and C. Evans (1995) "Some Empirical Evidence on the Effects of Monetary Policy Shocks on Exchange Rates", Quarterly Joumal of Economics, April.

Fuerst, T. (1992) "Liquidity, Loanable Funds, and Real Activity," Journal of Monetary Economics, 29, 3-24.

Grilli, V. and N. Roubini (1991) "Financial Intermediation and Monetary Policies in the World Economy", NBER Technical Working Paper No.104, May.

Grilli, V. and N. Roubini (1992) "Liquidity and Exchange Rates", Journal of International Economics, Vol.32, 339-352.

Grilli, V. and N. Roubini (1993) "Liquidity, Capital Controls, and Exchange Rates", Journal of International Money and Finance, Vol.12, 139-153.

Grilli, V. and N. Roubini (1995) "Liquidity and Exchange Rates: Puzzling Evidence form the G7 Countries," mimeo, Yale University, March.

Kim, S. and N. Roubini (1995) "Liquidity and Exchange Rates: A Structural VAR Approach," mimeo, Yale University, February.

Lucas, R.E. Jr. (1990) "Liquidity and Interest Rates," Journal of Economic Theory, April. 
Sims, C. and T. Zha (1995) "Does Monetary Policy Generate Recessions ? Using Less Aggregate Price Data to Identify Monetary Policy," manuscript, Yale University.

Schlagenhauf, D.E. and J.M. Wrase (1995) "A Monetary, Open Economy Model with Capital Mobility", Discussion Paper 67, Institute for Empirical Economics, Federal Reserve Bank of Minneapolis. 
Impulse Response Functions: Orthogonalized Shock to Interest Rates in G-7 Countries other than the U.S 7 Variable system
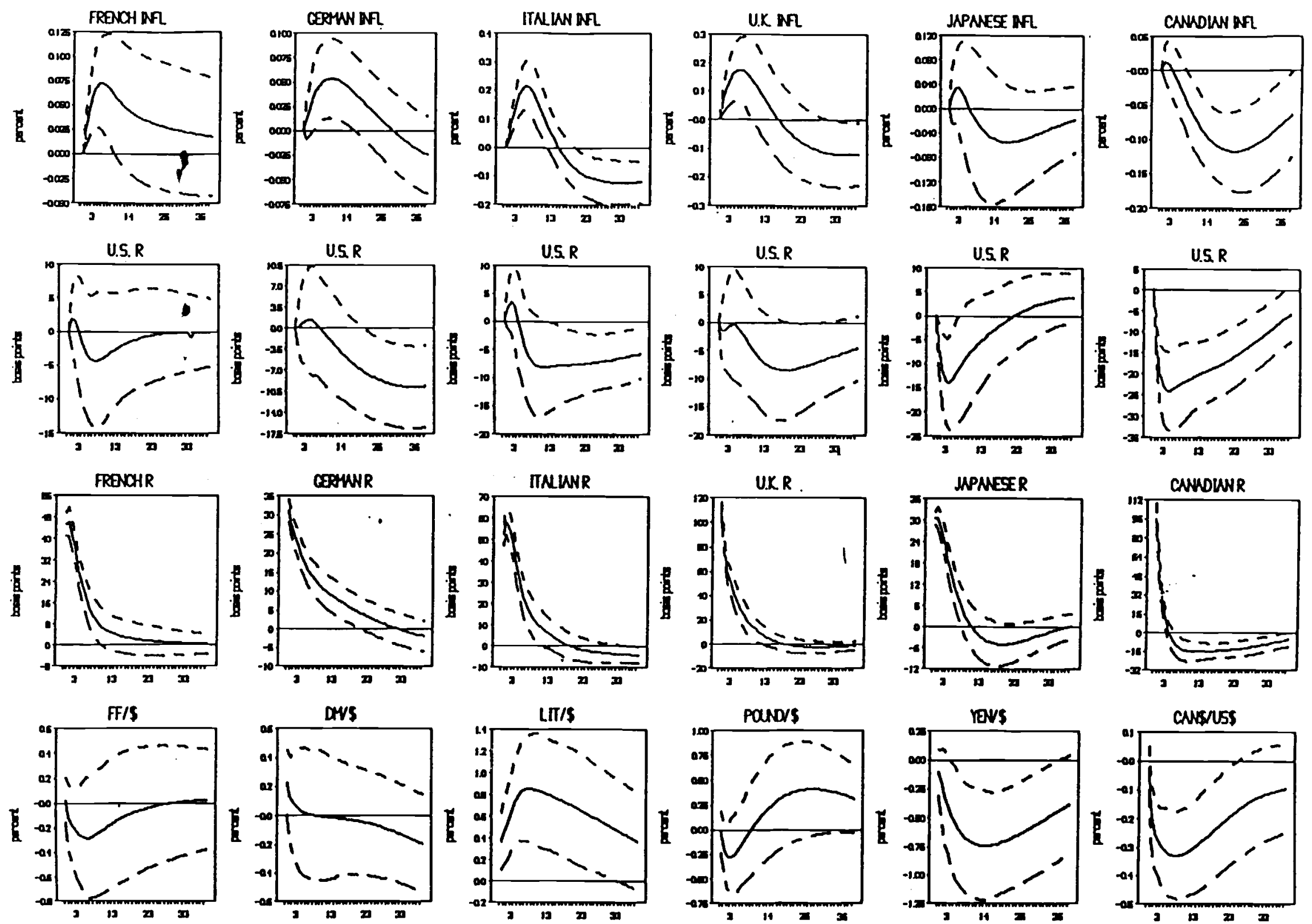

Column 1 shows the dynamic effect of an innovation in the French interest rate on the French inflation (INFL), the Fed Funds rate (U.S. R), the French interest rate (French R), and the nominal Franc - U.S. Dollar exchange rate $(\mathrm{FF} / \$)$. Columns 2 to 6 do the same for interest rates shocks in Germany, Italy, U.K., Japan and Canada. 


\section{Figure 2}

Impulse Response Functions: Orthogonalized Shock to the Differentlal between Short-Term and Long-Term Interest Rates in G-7. Countries other than the U.S.
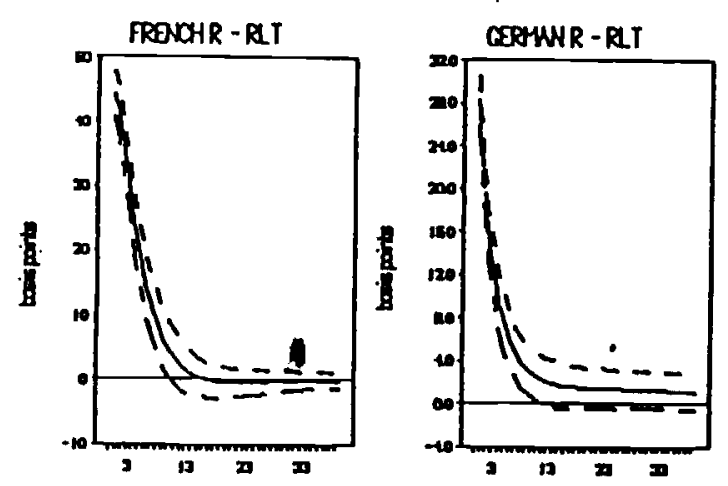

7 Variable System
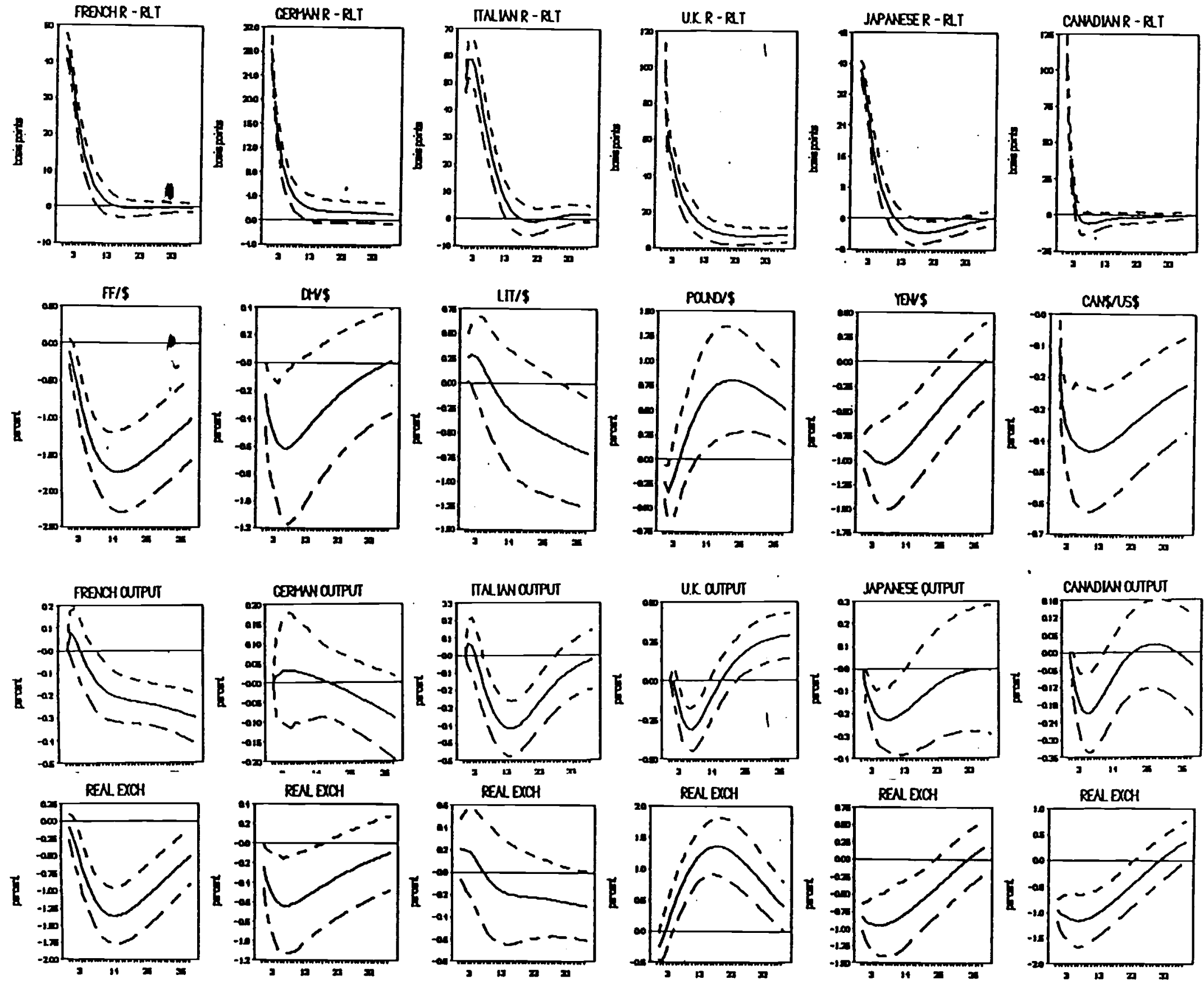

Column 1 shows the impulse responses following an innovation in the differential between short and long-term interest rates (French R-RLT) on the French differential (R-RLT), the Franc-U.S. Dollar nominal exchange rate, the French output and the Franc-U.S. Dollar real exchange rate. Column 2 to 6 do the same for shocks in Germany, Italy, U.K., Japan, and Canada. 
Figure 3 Impulse Responses to Monetary Policy Shocks

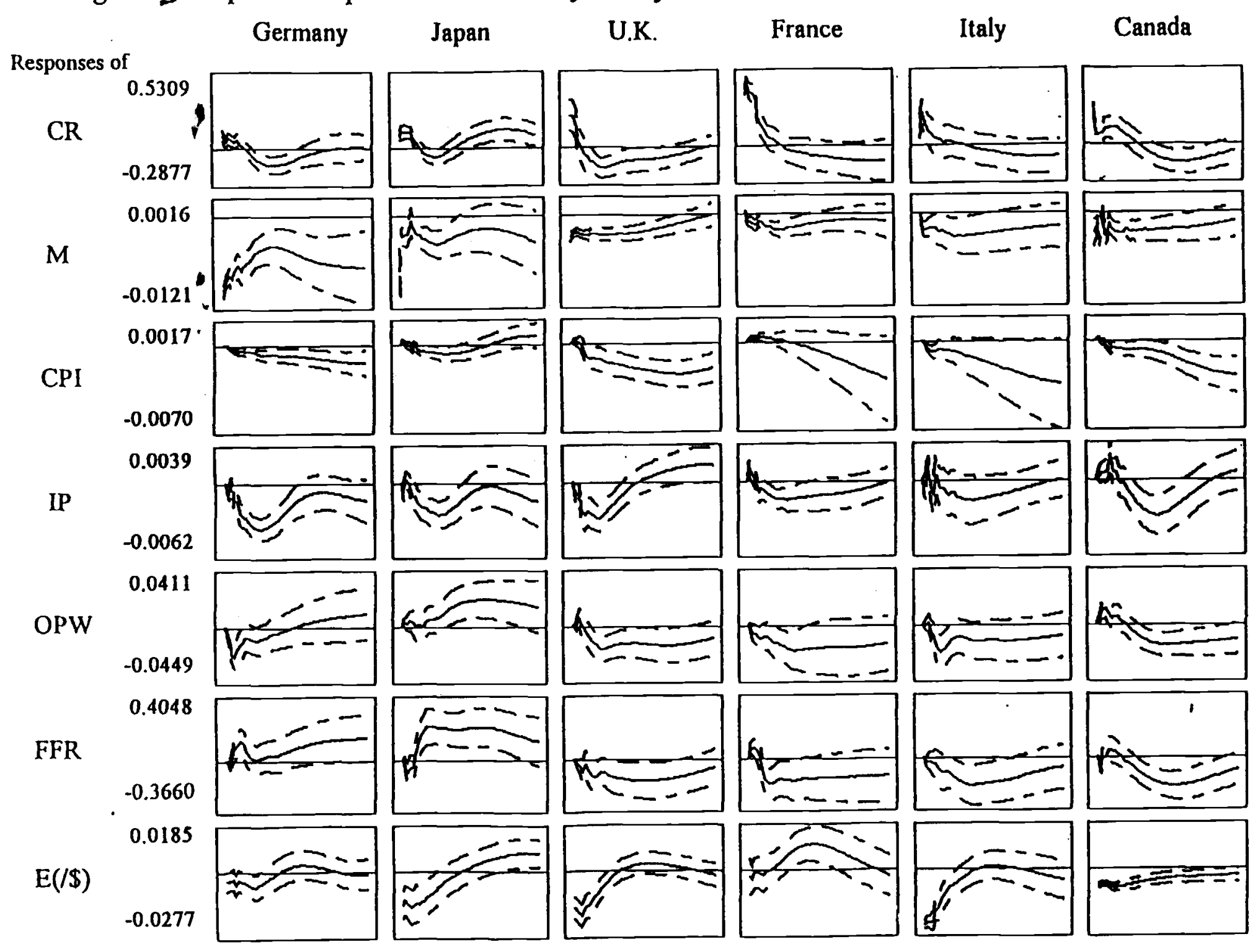

